\title{
The importance (or not) of patents to UK firms
}

By Bronwyn H. Hall ${ }^{\star}$, Christian Helmers ${ }^{\dagger}$, Mark Rogers ${ }^{\star}$, and Vania Sena ${ }^{\S}$

${ }^{*}$ Department of Economics, University of California at Berkeley, Berkeley, CA 94720, USA, and University of Maastricht; e-mail: bhhall@econ.berkeley.edu †Universidad Carlos III de Madrid, SERC LSE †Formerly Harris Manchester College, Oxford University (deceased) §University of Essex

\begin{abstract}
A surprisingly small number of innovative firms use the patent system. In the UK, the share of firms patenting among those reporting that they have innovated is about $4 \%$. Survey data from the same firms support the idea that they do not consider patents or other forms of registered IP as important as informal IP for protecting inventions. We show that there are a number of explanations for these findings: most firms are SMEs, many innovations are new to the firm, but not to the market, and many sectors are not patent active. We find evidence pointing to a positive association between patenting and innovative performance measured as turnover due to innovation, but not between patenting and subsequent employment growth. The analysis relies on a new integrated dataset for the UK that combines a range of data sources into a panel at the enterprise level.
\end{abstract}

JEL classifications: L21, L25, O34.

\section{Introduction}

One of the most puzzling findings in the empirical analysis of firms' patenting behaviour is the low proportion of patenting firms in the population of registered companies. Our investigation of this phenomenon in the UK finds that only $1.6 \%$ of all registered firms in the UK patent and that even among those that are engaged in some broadly defined form of R\&D, only around $4 \%$ have applied for a UK or European patent during our period of analysis (1998-2006). ${ }^{1}$ In our data, even in high-tech manufacturing sectors, which arguably produce the most patentable inventions, the share of patenting firms in the UK does not surpass $10 \%$. Restricting the high-tech sector to R\&D-doing firms that also innovate, the share of patenting firms increases only to $16 \%$. Findings for the US are similar:

\footnotetext{
${ }^{1}$ European means a patent that was filed with the European Patent Office (EPO).
} 
Balasubramanian and Sivadasan (2011) find that only 5.5\% of US manufacturing firms own a patent. Moreover, shares of patenting firms differ dramatically across sectors-even within the manufacturing industry; for example in the UK, manufacturing of chemicals and chemical products has a share of around $10 \%$ of patenting firms whereas publishing and printing has a share of only around $1 \%$. This suggests that (a) some firms do not automatically patent all of their patentable inventions, (b) some firms avoid the patent system altogether, either because of its cost or because patenting is perceived to yield no additional benefit, and (c) some innovations involve inventions that are not patentable.

In this paper we investigate three questions whose answers may shed some light on the reasons that relatively few firms patent. First, we look at the determinants of the perceived importance of patents and other IP mechanisms for securing the returns to innovation, as self-reported by firms. Second, we relate the actual, observed decision to patent to a set of firm characteristics and the perceived importance of patents to the firm and in the firm's sector. Finally, we ask whether patenting is associated with better innovative performance or with higher employment growth, controlling for many other factors. If it is, that suggests that the low patenting rate is of concern, whereas if patenting has only a limited association with performance, that could explain why relatively few firms find it worthwhile.

The analysis is based on a new firm-level dataset that combines detailed information on firms' self-reported innovation activities from the UK Community Innovation Survey (CIS) with firms' actual patent and trademark holdings. The combination of the different data sources allows us to overcome a number of problems that have plagued existing work on the determinants of a firm's patenting propensity. If patent data are available but not information on a firm's innovative activities, strong assumptions regarding firms' underlying innovative activities are required in order to measure a firm's patenting propensity. ${ }^{2}$ However, even when data on innovation input such as $R \& D$ are available, it is empirically difficult to determine whether patenting propensities differ due to differences in unobserved productivity, i.e., the way $\mathrm{R} \& \mathrm{D}$ is translated into patentable inventions, or due to genuine differences in patenting propensities (Brouwer and Kleinknecht, 1999). The availability of some information on innovation output, together with data on a firm's actual patent applications, allows us to partially overcome this problem and to assess the determinants of a firm's decision to patent conditional on innovating. Although innovation is possible without necessarily having patentable inventions, innovating firms are more likely to possess such inventions. There are few existing analyses of observed patenting behaviour that are able to control for the presence of an invention; most of those available use spending on R\&D as a proxy for innovative activity. However, formal R\&D is only

\footnotetext{
${ }^{2}$ The required assumption is that firms face the same decision conditional on a range of observable characteristics, that is, they have similar inventions that they can patent or protect in a different way such as maintaining them secret.
} 
a proxy for firms' innovative activity as inventions may result from a range of (even routine) activities and is therefore not exclusively an outcome of the targeted effort of R\&D. As we show empirically later in the paper, this phenomenon is more likely in service sectors than in manufacturing, the traditional sector studied using the R\&D proxy.

Despite these advances, our data is still of observational nature, that is, the variables of interest are subject to companies' endogenous choices. A company's decision to protect a specific invention through a patent or an alternative protection mechanism is far from random. This limits our ability to identify causal mechanisms that determine a firm's decision of how to appropriate returns to inventing and innovating. We are, therefore, constrained to pointing to robust empirical patterns in the data. This is a major shortcoming that applies to the literature on the decision to patent and its implications more generally due to the absence of experiments. ${ }^{3}$ In addition, although in principle we have a panel data set for analysis, the CIS resamples for each survey, so that the resulting panel is highly unbalanced. Thus exploiting variation over time is of little help in achieving identification of the parameters of interest.

Our results show that in general innovation of any kind is negatively associated with a preference for patents over secrecy or formal IP over informal IP, although the association is weakly positive in the case of manufacturing and very negative in Knowledge-Intensive Business Sectors (KIBS). Patent propensities vary greatly across type of innovation, firm size and industry. The most important, and wellknown, explanation of the low overall propensity to patent is that most firms are small and small firms are unlikely to patent. Another reason is that most UK firms are in sectors where patenting is not used much or where innovative activity is low. In addition, firms are less likely to patent if they have process innovations or innovations new to the firm, but not the market (as one might expect). Third, we provide some empirical evidence on the relationship of a firm's patenting decision to its subsequent performance and find that patents are positively associated with innovative sales performance but not significantly with employment growth. Thus there is some suggestion that they are associated with more successful innovations but not with overall performance. ${ }^{4}$

\footnotetext{
${ }^{3}$ In the context of patents it might not even be obvious how a randomised intervention should be designed to yield meaningful insights. Yet there is scope to exploit exogenous variation induced by policy interventions or idiosyncratic shocks to identify the effect of the variable of interest. In the innovation literature, examples exploiting such natural or quasi-experiments are rare. Exceptions include Scherer and Weisburst (1995) who use a decision in 1978 by the Italian Supreme Court ruling an existing law unconstitutional that excluded pharmaceuticals from patent protection in Italy to identify the effect of patent protection on innovation measured as R\&D and US patents. In a similar study, Sakakibara and Branstetter (2001) use a change in the Japanese patent law to identify the effect of the strength of patent rights protection on firms' $R \& D$ expenditure and patenting activity.

${ }^{4}$ However, our empirical framework is not suited for making counterfactual statements, i.e., we are unable to say whether patenting and innovative performance would still be positively correlated if more firms patented.
} 
This paper is organized as follows. Section 2 briefly summarizes the relevant literature that is based on the analysis of CIS data. Section 3 describes the structure and content of the dataset used for the analysis. Section 4 provides descriptive evidence on our principal research questions. Section 5 outlines our empirical approach and Section 6 discusses the corresponding results. Section 7 summarises the main findings.

\section{Literature}

In this section, we briefly review a number of studies using CIS data on innovations to study patenting. ${ }^{5}$ This is useful to frame our analysis within the existing research and to compare our results with existing findings. Hall et al. (2012a) offer a broader review of the existing literature on firms' choices between formal and informal IP. As we discuss there, both the theoretical and empirical literatures focus on the trade-off between secrecy and patenting, primarily because other methods of IP protection are likely to be complementary and used together, rather than obvious substitutes as in the case of secrecy and patenting. ${ }^{6}$

Brouwer and Kleinknecht (1999) uses the CIS 1 data (for the Netherlands) to study the determinants of a firm's decision to patent. The Dutch CIS 1 data also contain information on firm's patent holdings, which allows Brouwer and Kleinknecht to investigate the determinants of a firm's actual patent holdings. They find firm size, R\&D intensity, sales of innovative products, and R\&D collaboration agreements to be positively correlated with a firm's patenting propensity. Also firms in high-tech sectors appear to have higher patenting propensities. Arundel (2001) uses CIS 1 data for seven European countries to show that the propensity to use secrecy relative to patents falls with firm size (measured as R\&D expenses and employment) for product innovations, while the association is much weaker for process innovations.

Pajak (2010) uses firms' responses in the French CIS 4 on the importance of different protection methods to evaluate the determinants of a firm's choice between patenting and secrecy. His main variables of interest in determining a firm's choice are firm size and the size of the inventive step. As expected, Pajak finds that the use of patents is increasing in a firm's size (measured as employment). Moreover, for his sample of small firms in intermediate goods sectors, Pajak finds that firms reporting innovations new to the firm are more likely to use patents, whereas the same firms seem to prefer secrecy for inventions new to the market, which he considers in line with the theoretical

\footnotetext{
${ }^{5}$ There is a large earlier literature on the determinants of patenting in manufacturing which emphasizes the role of R\&D, exemplified by Scherer (1965) and Bound et al. (1984) that we do not review in the interest of brevity. For work that surveys firms on their use of IP, see Mansfield (1986), inter alia.

${ }^{6}$ As discussed in more detail in our literature review, it is also true that the use of patents and secrecy may be combined. For example, different components of an invention may be patented whereas others, such as the production method, may be kept secret. Alternatively, patent applicants may attempt to obscure enablement in a patent applications by for example increasing the complexity of filings.
} 
predictions of Anton and Yao (2004). This empirical finding should be interpreted with caution, however, as the sample size is small (72 firms) and the share of innovating small firms is less than $10 \%$. The results presented in this paper point to the opposite conclusion.

Heger and Zaby (2013) use data from the Mannheim Innovation Panel (MIP) (which represents the German CIS) to offer an explanation for the empirically observed variation in patent propensities across companies. The empirical analysis of patenting propensities is possible because the MIP contains firms' self-reported innovation measures as well as data on their patent applications. The authors show theoretically and empirically that the decision to patent depends on the effect on competition associated with the disclosure of information required by a patent. This effect varies across firms because it depends on the competitive advantage of companies. This variation in the cost of disclosure due to a patent translates directly into variation in patent propensities across firms.

The literature on the link between a firm's choice of patenting versus secrecy and its subsequent performance is much thinner. An exception is Hussinger (2006), who investigates the impact of this choice on innovative performance, measured as the share of sales due to new products. She also uses the MIP in combination with patent filings at the German Patent and Trademark Office, restricting the sample to R\&D-performing firms that report a product innovation. Hussinger finds patenting but not secrecy to be associated in a statistically significant and positive way with a firm's sales due to new products.

\section{Data}

The dataset used in our analysis consists of four components, which are all linked by a unique enterprise business register number: ${ }^{7}$

1. Business Structure Database (BSD);

2. UK Community Innovation Surveys (CIS) 3, 4, and 5;

3. UK and EPO patent data;

4. UK and Community (OHIM) trademark data.

The individual components are described in more detail in an online Appendix.

The linked dataset is a firm-level panel that contains detailed information on firm characteristics and innovative activities as well as patent filings over the nineyear period 1998-2006. Due to the stratified nature of the sampling of the CIS data and a changing sampling frame over time, the panel is highly unbalanced.

Because each CIS refers to several years (CIS 3 to 1998-2000, CIS 4 to 2002-2004 and CIS 5 to 2004-2006), we collapse the panel to three time periods which cover

\footnotetext{
${ }^{7}$ We conduct the analysis at the 'enterprise' level where an enterprise comprises all legal units under common control. The patent and trademark data is available only at the enterprise level which motivates us for consistency to conduct our analysis at the enterprise level.
} 
the entire period 1998-2006 (with the exception of 2001). ${ }^{8}$ This means that we look at patenting decisions any time over the three-year reference period of the CIS. Given the nature of the CIS, it is impossible to establish a closer link between an observed patenting decision in a given year and the reported underlying innovative activity. Because of this, our analysis is primarily cross-sectional and describes the general relationship between innovating and patenting behaviour across firms.

Table 1 shows the panel structure of the data, first for all firms matched to the CIS and then for the innovating sample we use in the subsequent analysis. ${ }^{9}$ The shaded rectangles indicate the availability of data and it is easy to see that most firms were sampled only once. Only 485 firms have been sampled in all three CIS waves. The largest overlap between CIS waves exists for CIS 4 and 5 with a total of 5,136 firms. Overall, only one quarter of the sample firms appear in at least two CIS waves (and only $17 \%$ for the innovating subsample). ${ }^{10}$

Table A1 in the online Appendix shows the distribution of observations across sectors for the full CIS sample and for the firms in our innovation sample. The population sector shares shown in the third column of Table Al have been produced using sampling weights to account for the stratified nature of the CIS samples. Because the sample stratification is largely by firm size, sectors with large firms are overweighted in our sample (that is, chemicals, food and beverages, hightech metals and machinery, transportation, and manufacturing in general) and those with more small firms underweighted (business and computer services, R\&D services, trade).

\section{Descriptive analysis}

This section provides descriptive evidence of the patenting activities of firms, looking at how patenting differs as a function of firms' underlying innovative activities and of the importance that firms attribute to different knowledge appropriation mechanisms. We also look at the relation between a firm's patenting decision and its innovative performance in terms of the sales of new products.

Table 2 shows the number of observations in our broad sample of firms that do any kind of R\&D or that introduce new products and/or processes during the relevant three-year period. Here R\&D is defined as either internal or external spending, the purchase of new hardware or software related to innovation, or

\footnotetext{
${ }^{8}$ All continuous variables from the BSD are averaged over each of the three CIS reporting periods, whereas we use the maximum value for discrete variables from the BSD and the registered IP data. This implies, for example, that the patent dummy variable measures whether a firm has taken out at least one patent during a three-year CIS reference period.

${ }^{9}$ The table omits a few observations that were missing key variables such as employment.

${ }^{10}$ Although the CIS panel has relatively little overlap, for economic data from the BSD we have considerably more overlap, which allows us to compute employment growth over the whole period, for example. Note that for our analysis, we restrict the data to sectors that have been sampled in all three CIS waves, i.e., we exclude retail trade (SIC 52), hotels \& restaurants (SIC 55), motion picture and video activities (SIC 921) and radio and television activities (SIC 922).
} 
Table 1 Panel structure

\begin{tabular}{lrrrrrr}
\hline Number of firms & Share (\%) & Sample firms ${ }^{*}$ & Share (\%) & CIS 3 & CIS 4 & CIS 5 \\
\hline 485 & $2.0 \%$ & 98 & $1.1 \%$ & $\mathrm{X}$ & $\mathrm{X}$ & $\mathrm{X}$ \\
396 & $1.7 \%$ & 148 & $1.7 \%$ & $\mathrm{X}$ & $\mathrm{X}$ & \\
5,136 & $21.6 \%$ & 1,098 & $12.8 \%$ & & $\mathrm{X}$ & $\mathrm{X}$ \\
214 & $0.9 \%$ & 74 & $0.9 \%$ & $\mathrm{X}$ & & $\mathrm{X}$ \\
5,905 & $24.8 \%$ & 1,595 & $18.6 \%$ & $\mathrm{X}$ & & \\
5,929 & $24.9 \%$ & 3,243 & $37.8 \%$ & & $\mathrm{X}$ & \\
5,725 & $24.1 \%$ & 2,321 & $27.1 \%$ & & & $\mathrm{X}$ \\
23,790 & 8,577 & & & & \\
\hline
\end{tabular}

Note: $\mathrm{X}$ indicates where data are available.

*The sample of innovating firms, cleaned, used for analysis

spending on training, design, or marketing related to innovation. ${ }^{11}$ The table shows that almost two-thirds of the firms undertake some kind of R\&D-related spending and one-third have an innovation. In fact, very few firms in our sample innovate without spending on some kind of R\&D.

The next three columns of the table show the numbers and shares of patenting firms in the large sample, and population shares, weighted using sampling weights to account for the stratified sampling of the CIS. Only $1.6 \%$ of the population of registered firms patent, whereas $2.9 \%$ of our sample does, again reflecting the slight up-weighting of larger firms. The figure is almost twice as large for manufacturing (5.9\%) and lower for the Knowledge-Intensive Business Sectors (1.7\%). Firms that both innovate and spend on R\&D are roughly twice as likely to patent. If we look at the unweighted shares, we see that the largest share of patenting firms is found in the manufacturing sector for firms that conduct R\&D and report an innovation $(10.7 \%)$. Although there are a small number of observations where a firm has applied for a patent even though it has not innovated during the past three years, the share of innovating firms that patent is over five times that for noninnovating firms $(645 / 10345=6.2 \%$ versus $240 / 20161=1.2 \%)$. In order to focus our attention on firms that have the potential to patent, the subsequent analysis in this paper is performed on the 10,345 firm-year observations shown in Table 2, those firms that introduced a product or process that was new to the firm or the market during the preceding three years. ${ }^{12}$

As discussed in the introduction, even when focusing our attention on innovative firms, there may still be important differences across the different types of innovation. Table 3 distinguishes between the four types of innovations

\footnotetext{
${ }^{11}$ Later in the paper, when we use R\&D expenditure, it covers only actual spending on R\&D for consistency with earlier work, and because coverage for the full set of innovation expenditures is relatively weak.

${ }^{12}$ The actual estimation sample consists of 10,093 observations, as we lose a few observations (about $2 \%$ ) because of missing or invalid data on the control variables.
} 
8 of 27 IMPORTANCE (OR NOT) OF PATENTS TO UK FIRMS

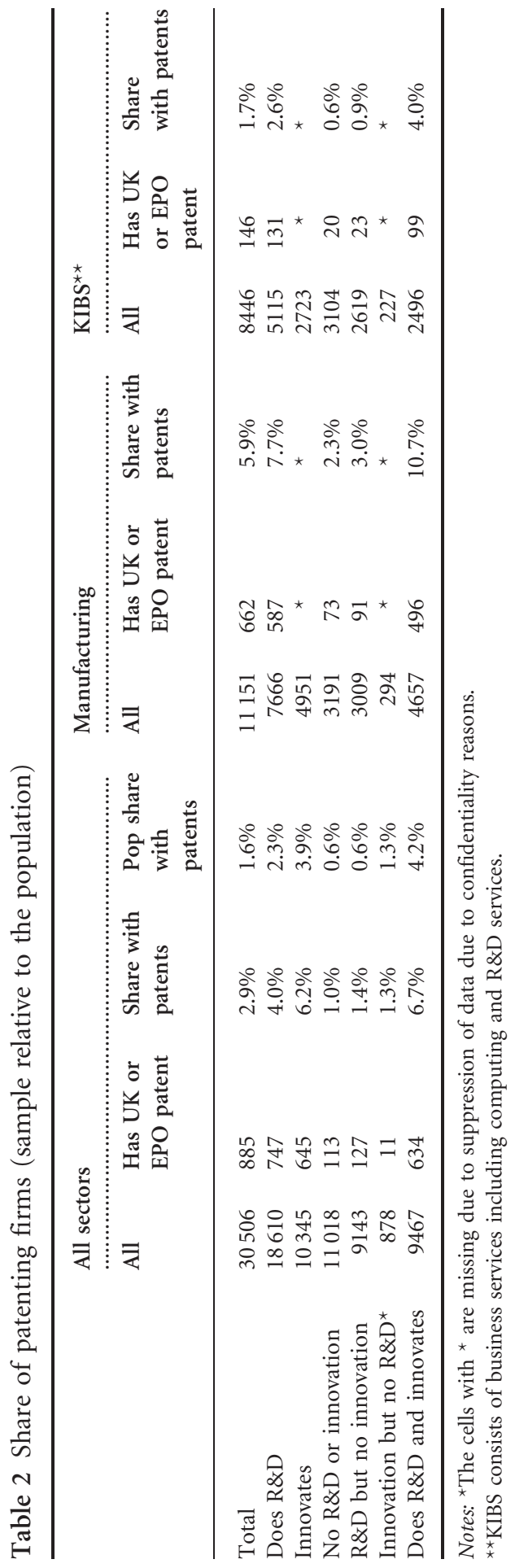


Table 3 Types of innovation

\begin{tabular}{|c|c|c|c|c|}
\hline & \multicolumn{4}{|c|}{ Innovators with } \\
\hline & $\begin{array}{l}\text { Product } \\
\text { New to } t\end{array}$ & $\begin{array}{l}\text { Process } \\
\text { market }\end{array}$ & $\begin{array}{l}\text { Product } \\
\text { New to } t\end{array}$ & $\begin{array}{l}\text { Process } \\
\text { not the market }\end{array}$ \\
\hline All firms & 4015 & 1645 & 3095 & 4009 \\
\hline $\mathrm{R} \& \mathrm{D}$ doers & 3797 & 1564 & 2893 & 3757 \\
\hline $\begin{array}{l}\mathrm{R} \& \mathrm{D} \text { doers who patent } \\
\text { Sample share innovating }\end{array}$ & 433 & 178 & 107 & 216 \\
\hline All firms & $13.2 \%$ & $5.4 \%$ & $10.1 \%$ & $13.1 \%$ \\
\hline $\mathrm{R} \& \mathrm{D}$ doers & $20.4 \%$ & $8.4 \%$ & $15.5 \%$ & $20.2 \%$ \\
\hline $\mathrm{R} \& \mathrm{D}$ doers who patent & $58.0 \%$ & $23.8 \%$ & $14.3 \%$ & $28.9 \%$ \\
\hline
\end{tabular}

Note: A negligible number of firms patent but do not do R\&D. There are 31,722 firms in the sample, including non-innovators.

reported in the CIS: (i) product innovation new to the market, (ii) process innovation new to the market, (iii) product innovation new to the firm, and (iv) process innovation new to the firm. The largest share of innovators reports product innovations new to the market or process innovations new to the firm. However, firms with product innovations that are new to the market are considerably more likely to patent (conditional on conducting R\&D). In particular firms that report a product innovation that is new to the market are about twice as likely to patent as firms that report a process innovation that is new to the market. These findings support both the view that product innovations that are generally novel are more likely to be based on a patentable invention and that process inventions are easier to keep secret and therefore less likely to be patented. ${ }^{13}$

Figure 1 shows the CIS answers with regard to the importance of the various IP protection mechanisms for our sample of innovating firms. Firms were asked in the CIS to evaluate the importance of the different mechanisms on a Likert scale between zero and three, where zero means a firm does not use this type of protection mechanism whereas three means that it represents a 'very important' mechanism for the firm. The figure shows the share of firms that rate each type of IP mechanism as of medium or high importance. As would be expected, the share of firms regarding any of the registered IP rights (registered designs, trademarks, patents) as important is substantially larger for patenting than for non-patenting firms. ${ }^{14}$ In contrast, patenting and non-patenting firms that are innovators rate

\footnotetext{
${ }^{13}$ The table also suggests that a small share of innovating firms patents despite reporting only innovations new to the firm. This may suggest that firms file patent applications despite a low likelihood of passing the novelty and inventive step thresholds. It is also possible that a patent was filed on an invention that is not yet incorporated into a product. However, due to the nature of our data, we cannot establish a link between a reported innovation and the observed patent application to investigate this further.
}

${ }^{14}$ See also Table A2 in the online Appendix. 


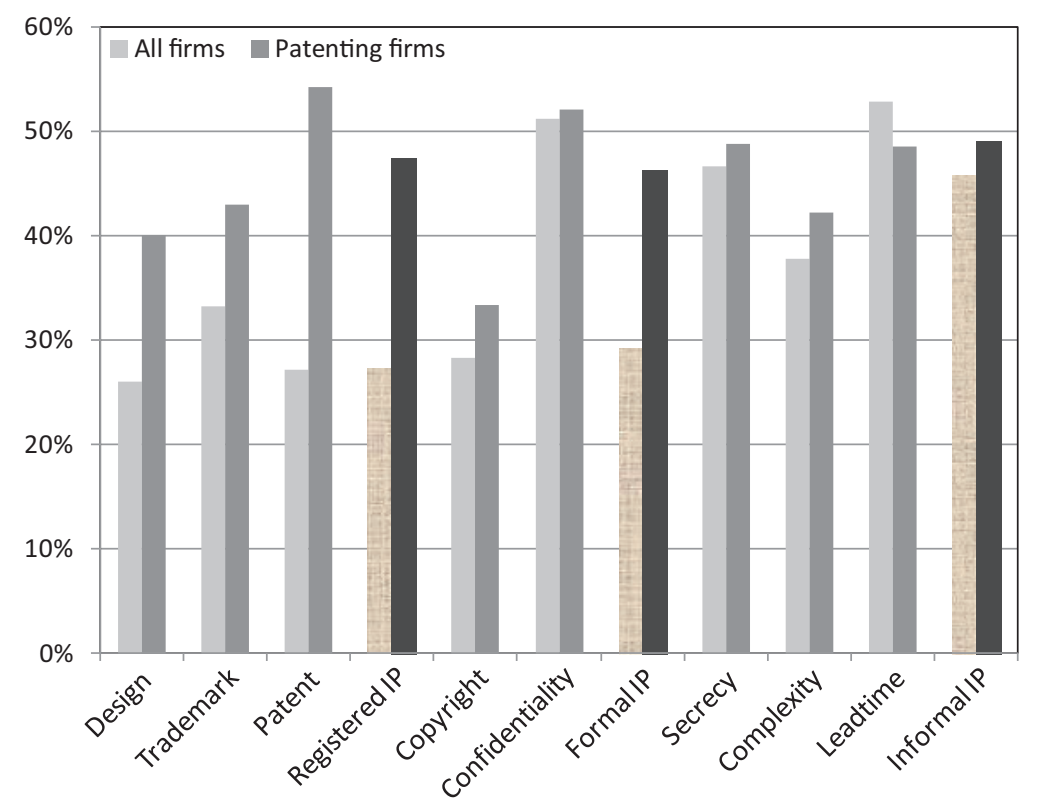

Fig. 1 Share of innovating firms rating different types of IP protection as medium or highly important.

informal IP mechanisms about the same. The results for registered IP suggest that if a firm patents, it is also more likely to think that other forms of registered IP are important. At the same time, patenting does not diminish the importance of informal IP protection, suggesting that firms may tend to use both mechanisms, possibly for different purposes.

Figure 2 provides evidence of the association of a firm's innovative activity and its share in sales due to product innovation, which can be considered as a measure of a firm's innovative performance. For ease of illustration, in Fig. 2, we have discretised firms' sales distribution into four size bands $(0 \%$; more than $0 \%$ and less than 10\%; between $10 \%$ and less than 25\%; and $25 \%$ and above). When looking at innovations that are 'new to the firm,' we do not see any strong pattern in the distribution of firms across turnover bands. Firms appear to be distributed similarly across turnover size bands independently of how highly they rank patents or secrecy. This suggests that there is little correlation between a firm's innovative performance in terms of turnover due to innovative products that are merely 'new to the firm' and the importance the firm attaches to the different protection mechanisms.

However, the data look different for innovations that are 'new to the market,' even though the average shares are approximately the same as those for 'new to the firm' sales. Firms that attach high importance to patents and/or secrecy also have a nonzero share of innovative sales. For example, only $25 \%$ of firms that have no 


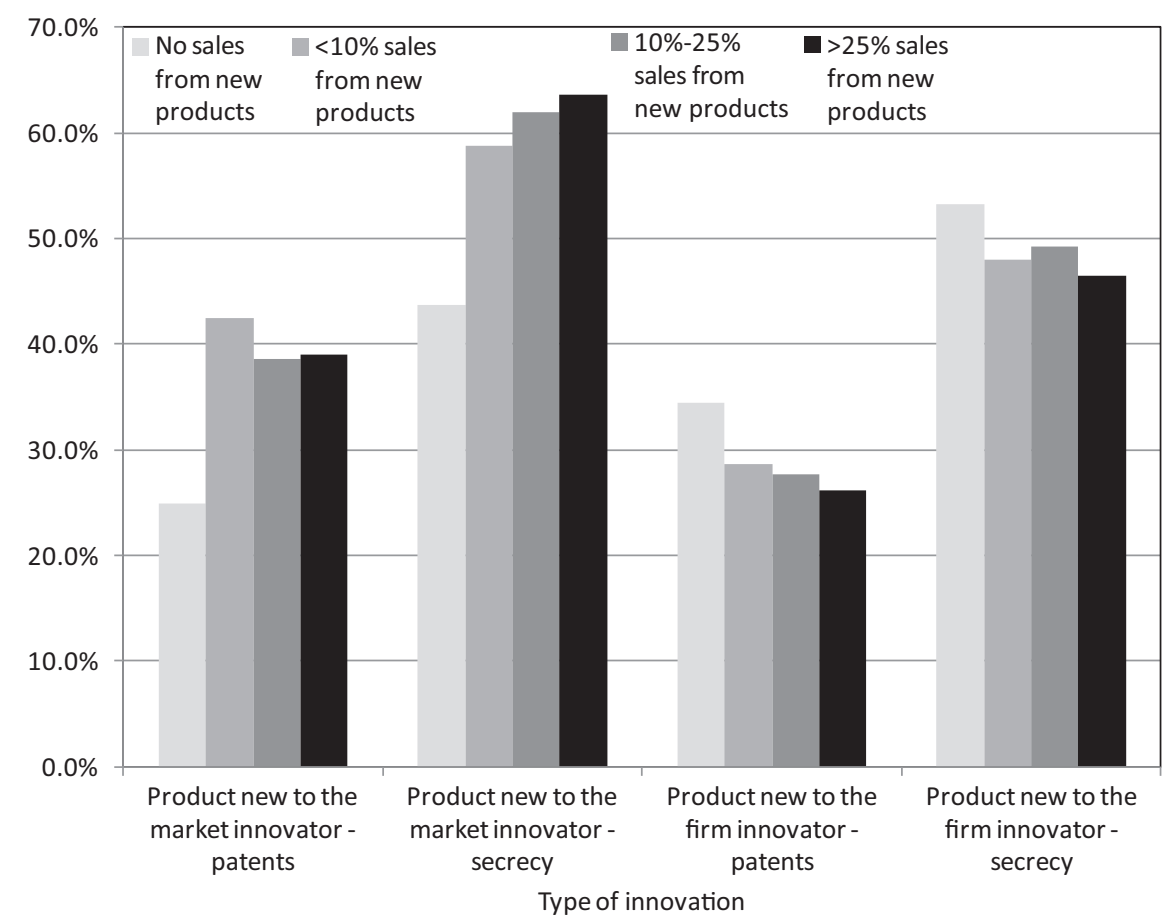

Fig. 2 Importance of patents and secrecy to product innovators.

turnover due to a product innovation that is 'new to the market' indicate heavy use of patents, whereas about $40 \%$ of firms with some innovative sales report heavy reliance on patents. The difference is similar with regard to the use of secrecy $(44 \%$ in the $0 \%$ turnover category and about $62 \%$ in other categories). Overall, this suggests that firms that regard patents and/or secrecy as important, and that have a product innovation that is 'new to the market' (i.e., high 'quality' invention), outperform (in terms of innovative sales share) firms that have such an innovation but do not use patents and/or secrecy. It also highlights the fact that although both secrecy and patents are used to protect inventions, even firms with innovative products new to the market seem to prefer secrecy to patents.

\section{Empirical analysis}

Our empirical analysis explores three relationships: (i) the determinants of a firm's preference for formal over informal IP protection; (ii) the determinants of the actual patenting decision; and (iii) the implications of these preferences and decisions for firm performance.

We limit the regression samples to firms that report a product and/or process innovation during the CIS reference period in order to ensure that in principle all 
firms face a decision of how to protect their innovation. To account for the type and to some degree also for the 'quality' of inventions, we also include information on whether an innovation is new to the market or new to the firm. In the case where a firm patents its invention, we are also able to use some patent indicators that have been shown to be correlated with invention value.

The first equation we estimate is the following:

$$
\begin{aligned}
\text { rel_ip }_{i c}= & \alpha+\beta_{1} \text { prodnM }_{i c}+\beta_{2} \text { prodnF }_{i c}+\beta_{3} \text { procn }_{i c}+\beta_{4} \text { procnF }_{i c} \\
& +\gamma X_{i c}+\phi f i p_{j c}+\theta i i p_{j c}+\delta_{c}+\mu_{j}+\varepsilon_{i c}
\end{aligned}
$$

where $i$ denotes a firm, $\mathrm{c}$ denotes a CIS wave, and $j$ denotes a sector. rel_ipic is a variable that measures the importance of one IP mechanism relative to another, following Arundel (2001), who suggested using the difference between the importance attributed to patents and secrecy. While levels may be difficult to compare at the firm-level, differences should be internally consistent. We consider two definitions of the relative importance variable: the difference between the formal IP and informal IP ratings and the difference between the patent and secrecy ratings. The former variable is roughly continuous, since the formal and informal IP measures are averages over a set of ratings, and we use ordinary least squares for estimation. The latter variable takes on only seven integer values $(-3,-2,-1,0,1,2,3)$ and we use ordered probit estimation when it is the dependent variable. The variables $\operatorname{prodn} M_{i c}$ and $\operatorname{procn} M_{i c}$ denote product and process innovations that are new to the market and variables prodn $F_{i c}$ and procn $F_{i c}$ denote product and process innovations that are new to the firm. Differences in the estimates associated with product innovations new to the market may arise if product inventions are more likely to represent patentable subject matter than process innovations. In addition, the variable that indicates whether a product innovation is 'new to the market' may also capture the costs associated with disclosing the invention to the public. If firms consider inventions characterised by a larger inventive step to be more valuable, then disclosing the information through a patent application may be less desirable to the firm and hence a firm may be more likely to opt for secrecy (Anton and Yao, 2004). Variable $f_{i p} i_{c}$ represents firms' perception of the importance of protection mechanisms in the form of formal intellectual property (registered design, trademark, patent, and copyright) at the SIC three-digit sector level. iip ic denotes the importance firms in the three-digit sector attribute to informal protection mechanisms including secrecy, lead time, and complexity. These variables are constructed as simple averages across all firms in an SIC three-digit industry.

$X_{i c}$ is a vector of firm-level characteristics including R\&D intensity and a dummy variable for firms with no R\&D, firm age, size, size squared, whether the firm is foreign-owned, whether the firm is a member of a group, and whether the firm exports. We also include a dummy variable that indicates whether the firm reported financial constraints to its innovative activity. 
The second equation we estimate is an equation for the probability a firm applies for a UK/EPO patent during the relevant period:

$$
p_{i c} \sim \Phi\left(\begin{array}{c}
\alpha+\beta_{1} \operatorname{prodn}_{i c}+\beta_{2} \operatorname{prodn}_{i c}+\beta_{3} \operatorname{procn}_{i c}+\beta_{4} \text { procn }_{i c} \\
+\gamma X_{i c}+\phi f i p_{j c}+\theta i i p_{j c}+\delta_{c}+\mu_{j}+\varepsilon_{i c}
\end{array}\right)
$$

$p_{i c}$ denotes firm $i$ 's actual patenting decision (firm $i$ is in sector $j$ and CIS wave $c$ ). This means that we reduce a firm's decision to a binary choice, either the firm decides to patent or not. ${ }^{15}$ The fact that information reported in the CIS refers to a three-year period means that we relate patent applications anytime during the three-year period to whether a firm reports an innovation over the same period. $\Phi($.$) is the normal distribution and we use a simple probit model for estimation.$ The independent variables are the same as those used in the first model (we add a dummy for either British or Community (OHIM) trademark ownership). Since we condition the sample on firms reporting a product and/or process innovation, we may interpret the decision not to patent as a decision to use some alternative mechanism to protect a given invention.

Existing survey evidence suggests that firms tend to use only some of their patents (Giuri et al., 2007), which means that the decision to patent per se may not be informative about its effect on performance. To gain more insight, in a third step, we analyse directly the relationship between a firm's observed decision to patent and its (innovative) performance. As performance measures, we use (a) the share of a firm's turnover that is due to innovations, with separate variables for innovations that are 'new to the firm' and 'new to the market'. This allows us to distinguish between the effect of patenting on a firm's sales based on imitation ('new to the firm') and innovation ('new to the market'). In addition, we also use (b) firm growth measured by employment as a performance measure. ${ }^{16}$ The model specification is thus:

$$
\text { perform }_{i c}=\alpha+\beta p_{i c}+\phi f i p_{j c}+\theta i i p_{j c}+\gamma X_{i c}+\delta_{c}+\mu_{j}+\varepsilon_{i c}
$$

where perform is the share of sales from products new to the market, the share of sales from products new to the firm, or employment growth. In eq. (3), the main object of interest is the variable $p_{i c}$ which indicates whether a firm has applied for a patent during the reference period. Most of the other variables are as in eq. (1), with the addition of an indicator of whether the firm also owns trademarks. We drop the financial constraints indicator, on the grounds that they should not affect the performance relationship, but only the choice of inputs.

\footnotetext{
${ }^{15}$ We are primarily interested in whether a firm applies for a patent at all and less in its patenting intensity which is why we collapse the number of patent applications to a binary variable. However, we also obtained results for specification (2) using patent counts as the dependent variable. The results are very similar to those reported in Table 5 and are available upon request.

${ }^{16} \mathrm{We}$ also investigated labour productivity as performance measures. However, labour productivity is only available for firms that are included in the ARD2. This means that the sample is considerably smaller and we therefore prefer to rely on the CIS-based turnover performance measure and employment growth computed using the BSD.
} 


\section{Results}

In this section we discuss the results from estimating eqs (1)-(3). Descriptive statistics for our regression sample are provided in online Appendix Tables A3 (univariate) and A4 (correlations).

\subsection{The relative importance of formal and informal IP}

Table 4 shows the results for the specification of the model in eq. (1). Columns (1) to (3) show results for the relative importance of formal versus informal IP and column (4) compares patents to secrecy. We include time dummies in all specifications and sector dummies in columns (2) to (4).

With respect to the key variables, the results for formal vs informal and patents vs secrecy are essentially the same. Larger firms are more likely to prefer formal IP to informal IP, but not patents to secrecy. In the latter case, financial constraints appear to be more important than size. All types of innovation are associated with a slight preference for informal methods to formal methods of protection, something which we also saw in Figs 1 and 2. One explanation may be that informal methods become relatively more important when a firm is innovative, reducing the gap between formal and informal methods (and leading to a fall in the relative importance of formal vs informal methods).

An interesting result in column (3) is that the coefficients on the corresponding sector-level variables are approximately equal to one and opposite in sign. This implies that a firm's rating of relative importance moves one for one with the threedigit sector level rating of relative importance (within two digit industries, which have been controlled for). Judging from the improvement in the small explanatory power of this regression, the sector level preferences are one of the more important drivers of the firm level preference.

The results for the $R \& D$ variables are somewhat puzzling. About half of the firms have R\&D on the BSD. Those that do not strongly prefer informal to formal IP and secrecy to patents. However, it is also true that for those that report $\mathrm{R} \& \mathrm{D}$, higher $\mathrm{R} \& \mathrm{D}$ intensity is also associated with a preference for informal IP protection over formal. This may reflect the fact that such firms are generally newer and smaller technology-intensive firms facing more uncertainty over the success of their inventions and innovations. Although age and size are controlled for, there is variation even among young small firms which is reflected in this coefficient.

\subsection{The decision to patent}

In Table 5 we show results for the probit estimation of eq. (2), the decision to patent. The first column presents results without sector dummies, and the remaining three columns include them. Patenting firms are larger, slightly more likely to be exporting, more likely to be a member of a group, but slightly less likely to be foreign-owned, which may reflect to some extent a tendency for 
Table 4 The relative importance of formal vs informal IP protection mechanisms (10,093 observations)

\begin{tabular}{|c|c|c|c|c|}
\hline \multirow{2}{*}{$\begin{array}{l}\text { Dependent variable } \\
\text { Variable }\end{array}$} & \multicolumn{3}{|c|}{$\begin{array}{l}\text { Formal vs informal } \\
\text { OLS }\end{array}$} & \multirow{2}{*}{$\begin{array}{l}\text { Patents vs secrecy } \\
\text { Ordered probit } \\
\text { (4) }\end{array}$} \\
\hline & (1) & (2) & (3) & \\
\hline $\begin{array}{l}\text { Product innovation } \\
\text { new to the market }\end{array}$ & $-0.12(0.02)^{\star * \star}$ & $-0.13(0.02)^{\star * \star}$ & $-0.12(0.02)^{\star * \star}$ & $-0.05(0.03)^{\star}$ \\
\hline $\begin{array}{l}\text { Process innovation } \\
\text { new to the market }\end{array}$ & $-0.17(0.02)^{\star * *}$ & $-0.17(0.02)^{\star \star *}$ & $-0.16(0.02)^{\star * \star}$ & $-0.12(0.03)^{\star * *}$ \\
\hline $\begin{array}{l}\text { Product innovation } \\
\text { new to the firm }\end{array}$ & $-0.06(0.02)^{\star * *}$ & $-0.06(0.02)^{* * *}$ & $-0.06(0.02)^{* * *}$ & $-0.07(0.03)^{\star *}$ \\
\hline $\begin{array}{l}\text { Process innovation } \\
\text { new to the firm }\end{array}$ & $-0.12(0.02)^{\star * *}$ & $-0.12(0.02)^{* * *}$ & $-0.11(0.02)^{* * *}$ & $-0.12(0.02)^{* * *}$ \\
\hline $\begin{array}{l}\text { Formal IP important in } \\
\text { the three-digit sector }\end{array}$ & & & $1.26(0.07)^{* * *}$ & \\
\hline $\begin{array}{l}\text { Informal IP important in } \\
\text { the three-digit sector }\end{array}$ & & & $-1.17(0.07)^{\star * \star}$ & \\
\hline D (financial constraints) & $-0.02(0.02)$ & $-0.02(0.02)$ & $-0.02(0.02)$ & $-0.06(0.02)^{* * *}$ \\
\hline Log (R\&D per employee) & $-0.05(0.01)^{\star * *}$ & $-0.05(0.01)^{\star * *}$ & $-0.05(0.01)^{\star * *}$ & $-0.05(0.01)^{\star * *}$ \\
\hline D (no R\&D) & $-0.16(0.04)^{\star * *}$ & $-0.16(0.04)^{\star * \star}$ & $-0.15(0.04)^{\star * *}$ & $-0.15(0.06)^{\star * *}$ \\
\hline Log age & $0.00(0.01)$ & $-0.00(0.01)$ & $-0.00(0.01)$ & $0.03(0.02)^{\star}$ \\
\hline Log employment & $0.01(0.01)$ & $0.01(0.01)^{\star * *}$ & $0.01(0.01)^{\star \star * *}$ & $-0.02(0.02)$ \\
\hline Log employment squared & $-0.00(0.002)$ & $-0.00(0.002)$ & $-0.00(0.002)$ & $-0.005(0.003)$ \\
\hline D (exports) & $-0.05(0.04)$ & $-0.04(0.04)$ & $-0.04(0.04)$ & $-0.05(0.05)$ \\
\hline $\mathrm{D}$ (member of a group) & $0.02(0.02)$ & $0.02(0.02)$ & $0.02(0.02)$ & $0.04(0.03)$ \\
\hline $\mathrm{D}$ (foreign-owned) & $0.01(0.02)$ & $0.01(0.02)$ & $0.01(0.02)$ & $0.03(0.03)$ \\
\hline 15 sector dummies & No & Yes & Yes & Yes \\
\hline Standard error & 0.790 & 0.789 & 0.777 & \\
\hline R-squared & 0.023 & 0.028 & 0.058 & 0.013 \\
\hline
\end{tabular}

Notes: Heteroskedastic-consistent standard errors clustered on enterprise are shown in parentheses. Period dummies for the three different CIS waves are included in all regressions.

foreign-owned UK enterprises to file patents under their parent name (and therefore not be matched to our sample). They are also more likely to use trademarks.

The regressions show strongly that patenting is associated with new-to-themarket innovation and not with new-to-the-firm innovation (except when the sector dummies are left out). We view this as validation of the 'new-to-themarket' concept. Although it is a long way from a 'novel' invention (one of the statutory requirements for a patent) to a product 'new-to-the-market,' these regressions indicate that the two are related, with such a product innovation essentially doubling the probability that a firm will patent.

In the previous table, we found that a firm's perception of the relative importance of formal over informal IP was influenced by the sectoral perception, but this relationship does not translate to the patenting decision of the firm. The sectoral rating of the importance of formal vs informal IP is not significant, whereas firms that rate formal IP highly are indeed more likely to patent.

Our preliminary conclusions from this investigation into the reasons for the low patenting rate among UK firms are the following. First, only one third of firms have 


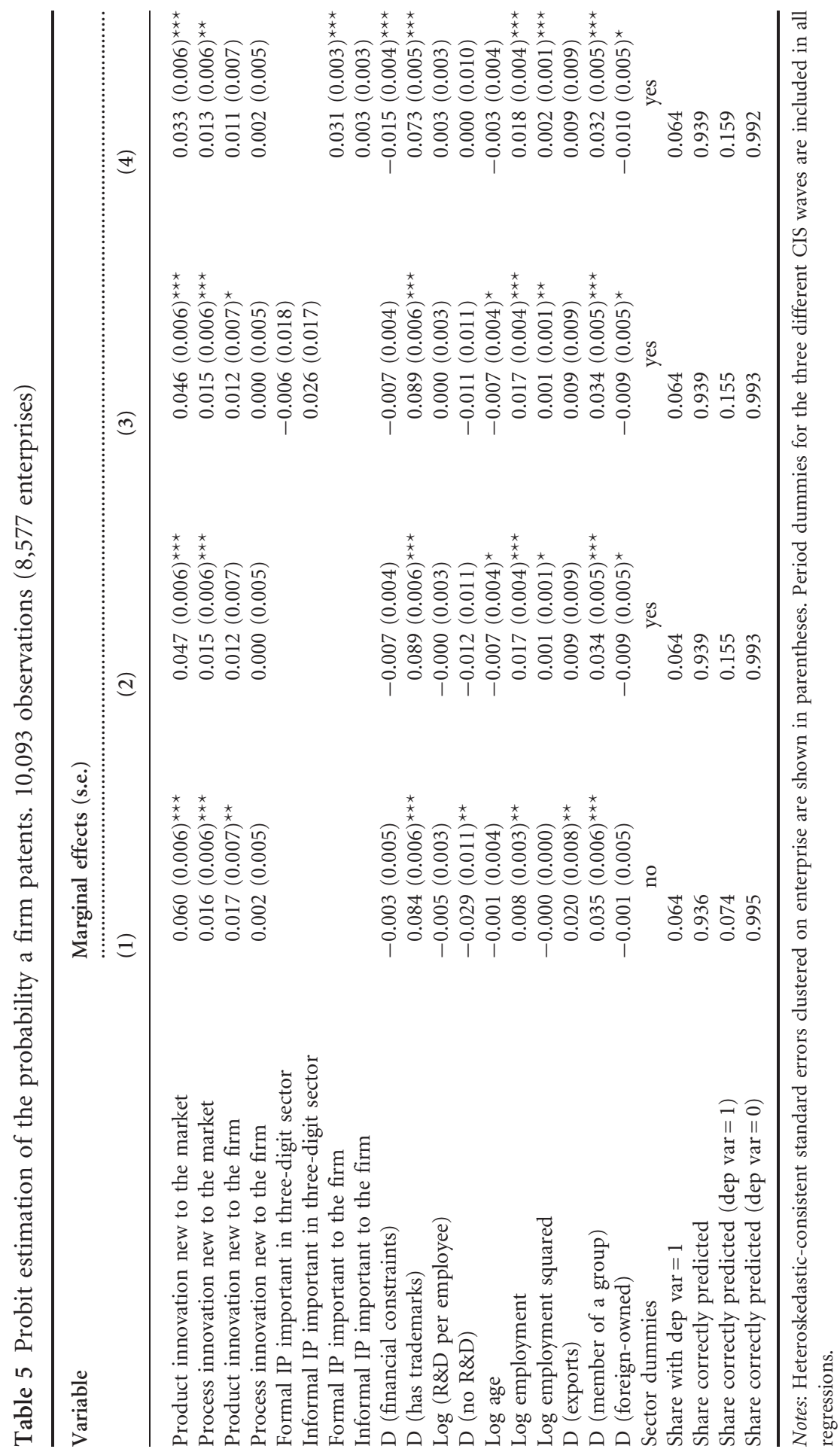


any innovations during a three-year period. Second, only about half of those have innovations new to the market. So at most, we might expect about $18 \%$ of the firms to patent. In addition, size plays an important role, as we can see in Figs 3 and 4. Figure 3 uses the regression results in Table 4 to show the predicted patenting propensity as a function of size for four types of firms in the metals and machinery sector: non-innovating and non-R\&D-doing, innovating and nonR\&D-doing, new-to-the-firm innovating and R\&D-doing, and new-to-the-market innovating and R\&D-doing. As expected, there are huge differences in expected patenting propensities for these four types of firms. But it is important to observe that almost all (about 90-95\%) of our firms lie in the region below 500 employees, and that the median firm has about 50 employees. At that size, all but the new to the market innovators have patenting propensities less than $10 \%$. So size explains a lot. ${ }^{17}$

Figure 4 shows that another explanation is differences across sectors, as expected. It shows the patenting propensity-size distribution for a new-to-the-market innovator that does $\mathrm{R} \& \mathrm{D}$ in five different sectors, ranging from the least patentintensive (financial intermediation firms) to the most (R\&D services firms). At the median firm size, the propensities range from $1 \%$ to almost $50 \%$. In fact, the pseudo R-squared from a regression of patenting on size, sector, and survey year alone is 0.18 ; adding the additional variables to the model does not improve its prediction accuracy over this simple regression, even though they are significant in some cases.

A final explanation we have uncovered is in the attitudes of the firms surveyed by the CIS. On average, all types of innovators, including new-to-the-market innovators, rate informal means of protection, especially secrecy, as a more important IP protection mechanism than patents, which suggests that they are likely to place more reliance on that method of protection. Those firms that do choose to patent also tend to have trademarks, suggesting that some firms like to use formal IP of all kinds, whereas others do not.

\subsection{Innovative performance}

This section analyses directly the relationship between a firm's choice to patent an invention (or maintaining it as a secret) and its innovative performance, conditional on the firm having some kind of innovation. We show results for the analysis of the relation between two measures of innovative performance (sales of products new to the firm and sales of products new to the market) and a firm's decision to patent. Following the literature (Mairesse and Mohnen, 2010), we transform the sales share with a logit transform so that the dependent variable is quasi-normally distributed and the coefficients of the regression are close to elasticities or

\footnotetext{
${ }^{17}$ This confirms earlier findings by Rogers et al. (2007a), in which the authors found a substantially larger share of firms in the large-firm category to patent than among SMEs. They also found patenting companies in the large-firm category to file considerably more applications than firms in the small- and medium-size category.
} 


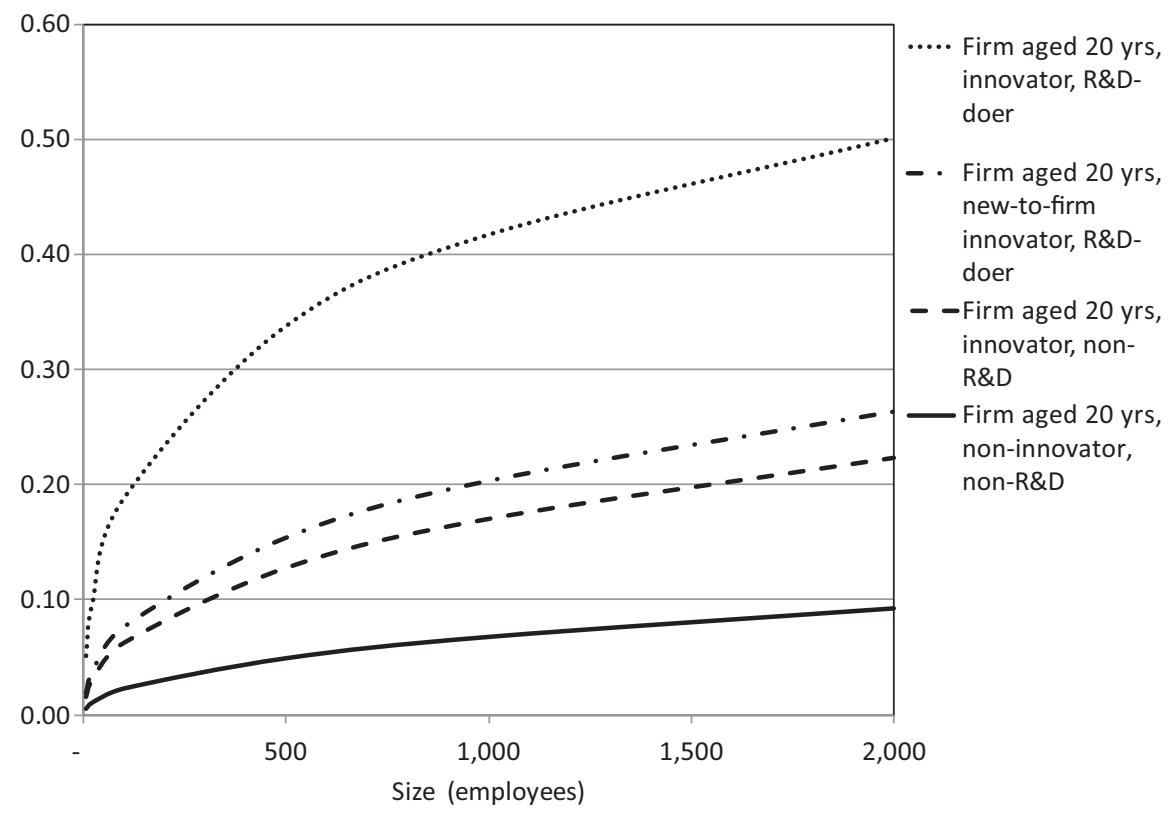

Fig. 3 Probability of patenting - metals and machinery sector.

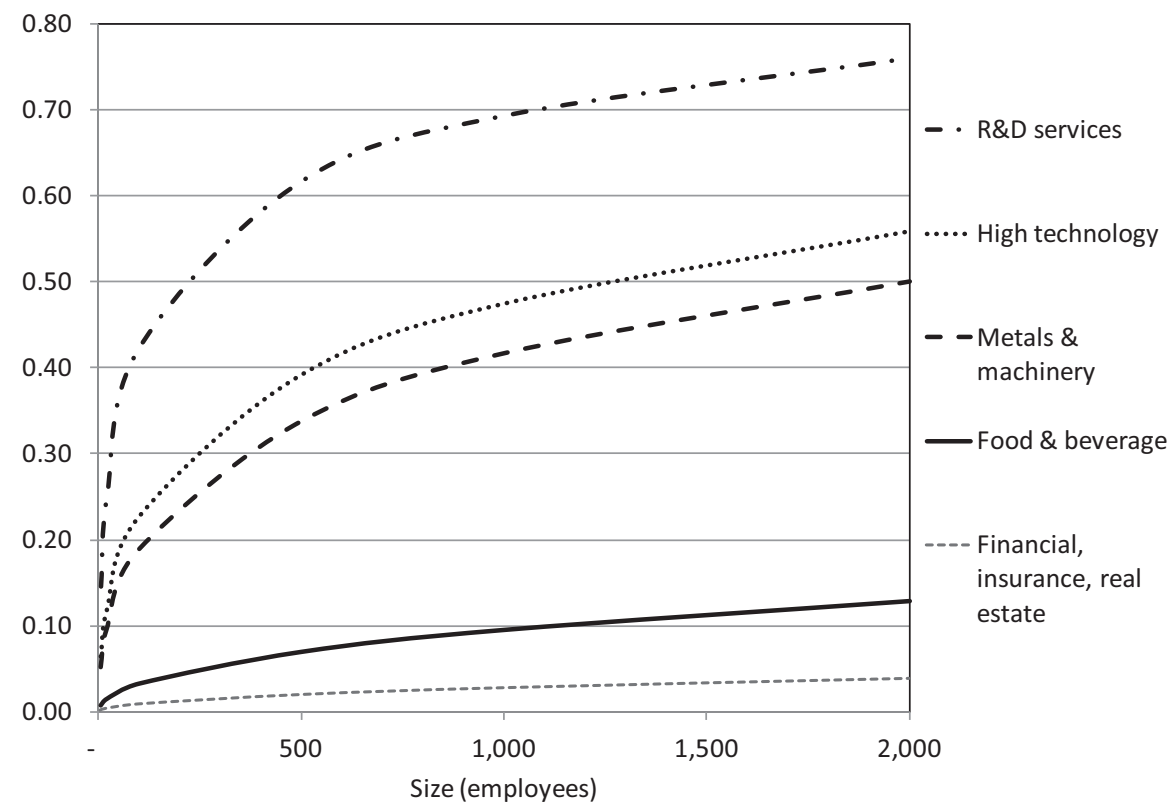

Fig. 4 Probability of patenting — innovating, R\&D-doing firms aged 20 years. 
semi-elasticities. To see this, note that the estimated coefficient associated with the variable $X$ in such a regression is the following:

$$
\beta=\frac{\partial \log [s /(1-s)]}{\partial X}
$$

where $s$ is the sales share. The semi-elasticity of $s$ with respect to $X$ is therefore:

$$
\frac{\partial \log s}{\partial X}=\beta(1-s)
$$

which is approximately equal to $\beta$ when $s$ is small, and declines towards zero as $s$ becomes large.

Columns (1) and (2) of Table 6 show the results when we consider only product innovations that are 'new to the market,' which we consider to be 'true' innovations that could in principle be patentable. The most salient finding is the large positive coefficient associated with the patent dummy variable, which suggests a strong positive association between a firm's decision to rely on a patent and its performance in terms of share in turnover due to an innovation. Having applied for a patent during the period increases the share of turnover from new products by about $50 \%$ at the mean share of $8 \%$. Clearly, this does not imply any causal effect of patents on innovative sales, as we cannot rule out potential reverse causality or other unobservables correlated with patenting driving this effect. However the use of patents suggests that the firm has a more marketable innovation and is operating in a market segment where formal IP protection is important. Having trademarks also has an additional positive impact on new-to-the-market innovative sales.

Columns (3) and (4) of Table 6 show the results when we consider innovative sales from product innovations that are 'new to the firm'. These are likely to be imitations of existing innovations and therefore far less patentable than innovations that are considered to be 'new to the market'. This is reflected in the results shown - the patenting dummy is not statistically significant in either of the specifications shown, nor is the trademark dummy or the sector-level importance of formal IP. This means that the share of turnover generated with products that are derived from innovations that are only 'new to the firm' is not associated in a statistically significant way with a firm's observed patenting behaviour.

In contrast, most of the coefficients associated with the other regressors in columns (3) and (4) display the same signs and similar magnitudes as in the first two columns of Table 6, with two exceptions: R\&D intensity and exports. $\mathrm{R} \& \mathrm{D}$ intensity is negatively associated with new-to-the market-sales but not with new-to-the-firm sales. This may be because the most R\&D-intensive firms do not produce products, but instead license their results to producing firms. In contrast, exporting firms have approximately $10 \%$ higher share of sales of products new to the firm, but about the same share of sales of products new to the market, suggesting that they are more likely to be engaged in exploiting existing innovations over a broader market rather than creating new ones. 


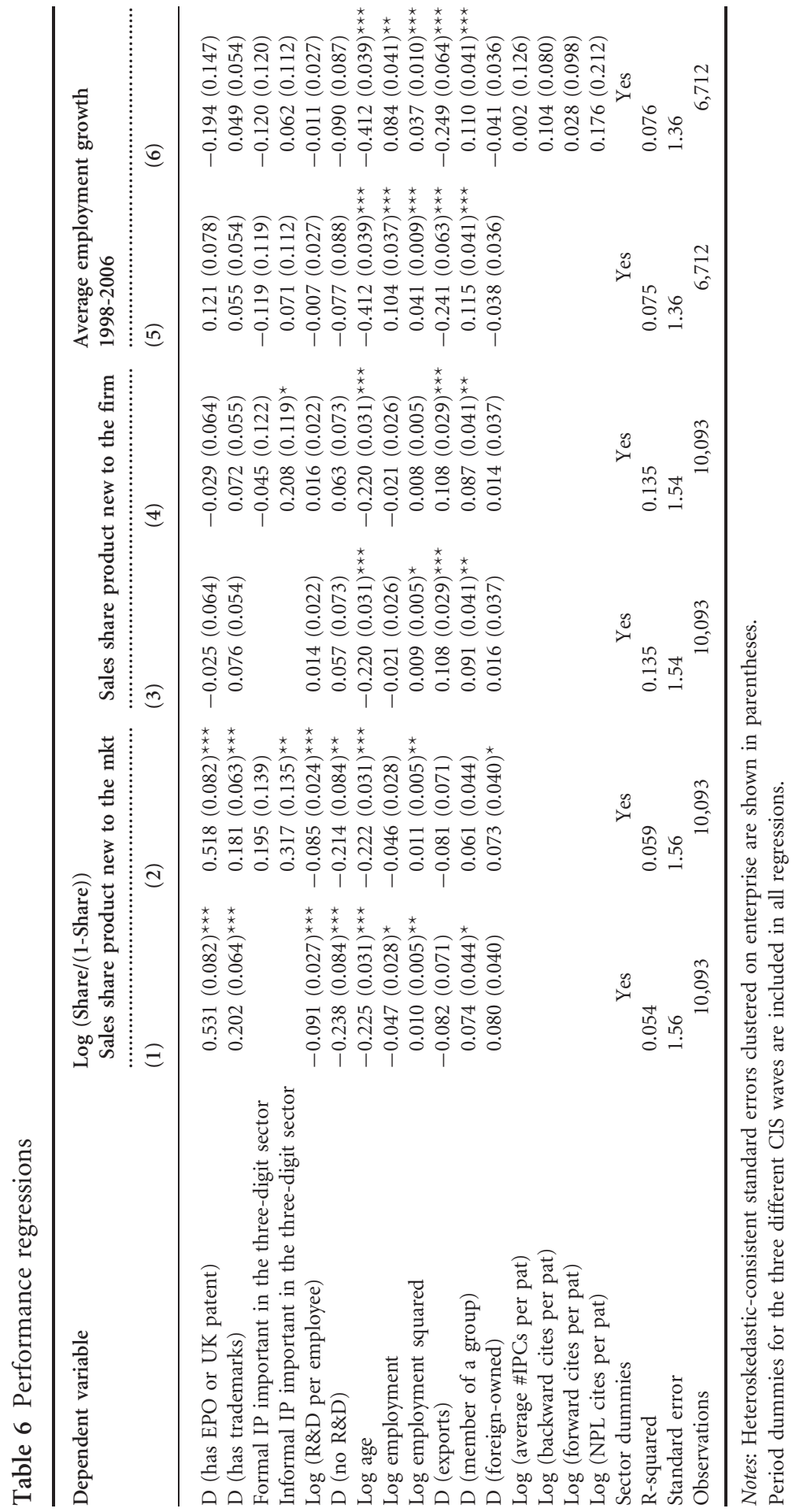




\subsection{Growth performance}

The last two columns of Table 6 use employment growth as an indicator of firm performance. ${ }^{18}$ Employment growth regressions have a long history and raise a number of econometric specification issues; for a review of these, see Hall (1987). That paper explores the role of measurement error and sample selection in estimating the growth-initial size relationship and reports two main findings: (i) measurement error in employment appears to introduce little bias in the size coefficient and (ii) there did appear to be a sample selection effect whereby smaller firms were more likely to exit, but this was confounded with size-related heteroskedasticity and possibly nonlinearity in the relationship. The conclusion was that attrition bias was likely to be rather small. Since here we are using a similar sample of UK firms and we are mainly concerned with the influence of the IPrelated variables on growth, we control for size but do not investigate measurement error and attrition biases, on the grounds that they are likely to be small.

We rely on the BSD data to construct the employment growth measure as the average annual growth rate over the number of years available for each firm between 1998 and 2006. We show the results of regressions of the growth rate on whether the firm has a patent, whether it has a trademark, and the sectoral importance of formal and informal IP as well as the controls, time, and sector dummies. All variables are measured at the beginning of the period (either 1998 or later if the firm enters the sample later). The results suggest a positive association between patenting and employment growth, but one that is statistically insignificant. Firms with patents have growth rates that are on average 12\% (in level) above those without patents, controlling for sector, size, age, R\&D, exporting, foreign ownership, and group membership.

Consistently with the new-to-market innovation performance results, we find that older firms grow more slowly and group members grow faster. In contrast to those results, exporting firms exhibit worse employment growth. Controlling for a firm's own patenting, the sectoral importance of formal and informal IP is not associated with growth, unlike the case of innovative sales.

Our final exploration in the last column also looks at whether several patent indicators that are known to be associated with patent value have any relationship to employment growth. That is, if we control for the quality of the inventions that are patented as well as the simple fact that at least one patent was applied for, can we see any relationship? The indicators we use are the average number of distinct classes (IPCs) per patent, the number of forward citations received per patent, the number of backward citations made per patent, and the number of citations to the nonpatent literature made per patent, all in logs. Unfortunately none of them enter significantly, and the net effect of these variables is to weaken the coefficient on

\footnotetext{
${ }^{18}$ Rogers et al. (2007b) analyse the association between firms' patenting decision on subsequent growth for the population of SMEs in the UK. Due to data limitations they are constrained to using growth in total assets and turnover as performance measures. Their results also suggest no statistically significant correlation between a firm's patenting activity and its asset and turnover growth.
} 
the simple patent dummy, with little impact on the other variables in the model. Our conclusion is that we may have too small a sample of patenting firms (recall that only $6 \%$ of innovating firms patent) to obtain much precision using these indicators.

\subsection{Sectoral differences}

In Tables 7 and 8 we look at how our estimates differ across two major sectors involved in innovation: a traditional $\mathrm{R} \& \mathrm{D}$-intensive sector, manufacturing, and a service sector, that relies less on R\&D but innovates heavily, Knowledge-Intensive Business Services (KIBS), which consists of business services (2003 UK SIC 71 and 74), computer services (SIC 72) and R\&D services (SIC 73). The contrast is of interest for two reasons: first, because the innovation process in the two sectors is quite different, with manufacturing being more 'technological' in general, and second, because the KIBS sector is growing relative to manufacturing. ${ }^{19} 11.5 \%$ of the observations in the manufacturing sample have a patent, whereas only $3.9 \%$ of the KIBS sector observations have a patent.

The first two columns of Table 7 present results for the ordered probit regression with the relative importance of patents vs secrecy as a dependent variable. Innovating firms in the two sectors clearly weight the importance of patents vs secrecy differently: manufacturing firms have a slight positive preference for patents if they are new-to-the-market product innovators, but prefer secrecy if they are process innovators (as expected). On the other hand, innovating firms in KIBS strongly prefer secrecy to patents. This finding also holds for formal IP vs informal IP in general (not shown). None of the other firm characteristics seem to have an influence on their rating of patents vs secrecy in both sectors, with the exception of firm age and R\&D intensity in manufacturing.

The last two columns present the patenting probability estimates for the two sectors. In the manufacturing sector innovating firms (other than mere new-tothe-firm process innovators) are more likely to patent, whereas only new-to-themarket product innovation is associated with patenting in KIBS. For both manufacturing and KIBS, being in a sector that rates formal IP protection as important is associated with patenting, as is size, being a member of a group, and financial constraints (negatively). Thus the main contrast between manufacturing and KIBS is that patenting is slightly more strongly associated with innovation in the former, whereas it is more strongly associated with exporting in the latter. This suggests some heterogeneity within both sectors-large exporting firms that are in a group and not financially constrained use patents, whereas the other smaller firms are much less likely to.

Table 8 presents the performance regressions for the two sectors. First, we note that the strongest and most stable relationship is that older firms have lower innovative sales and lower growth, in both sectors as in the aggregate. Having a

\footnotetext{
${ }^{19}$ Between 2005 and 2010, manufacturing employment in the UK declined 37\%, while employment in Professional, scientific, and technical services grew 32\% (Wilson and Homendiou, 2012, Table 3.4).
} 
Table 7 Patenting and its relative importance by broad sector

\begin{tabular}{|c|c|c|c|c|}
\hline \multirow{3}{*}{$\begin{array}{l}\text { Dependent variable } \\
\text { Variable }\end{array}$} & \multirow{2}{*}{\multicolumn{2}{|c|}{ 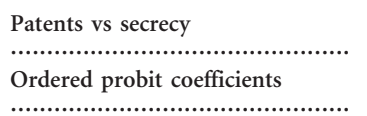 }} & \multirow{2}{*}{\multicolumn{2}{|c|}{$\begin{array}{l}\mathrm{D} \text { (patent app during the period) } \\
\text { Marginal effects (s.e.) }\end{array}$}} \\
\hline & & & & \\
\hline & Manufacturing & KIBS & Manufacturing & KIBS \\
\hline Product innovation new to the market & $0.07(0.04)^{*}$ & $-0.14(0.06)^{* *}$ & $0.05(0.01)^{\star \star *}$ & $0.03(0.01)^{\star \star *}$ \\
\hline Process innovation new to the market & $-0.12(0.05)^{* *}$ & $-0.09(0.06)$ & $0.02(0.01)^{\star}$ & $0.00(0.01)$ \\
\hline Product innovation new to the firm & $0.03(0.04)$ & $-0.15(0.06)^{\star *}$ & $0.03(0.01)^{\star}$ & $0.01(0.01)$ \\
\hline Process innovation new to the firm & $-0.09(0.03)^{* * *}$ & $-0.18(0.05)^{* * *}$ & $0.00(0.01)$ & $-0.00(0.01)$ \\
\hline Formal IP important to the firm & & & $0.06(0.005)^{\star * *}$ & $0.03(0.005)^{* * *}$ \\
\hline Informal IP important to the firm & & & $-0.00(0.01)$ & $0.01(0.00)^{*}$ \\
\hline $\mathrm{D}$ (financial constraints) & $-0.03(0.03)$ & $-0.06(0.04)$ & $-0.03(0.01)^{* \star *}$ & $-0.01(0.01)^{\star *}$ \\
\hline Log (R\&D per employee) & $-0.05(0.02)^{\star *}$ & $-0.04(0.03)$ & $0.00(0.00)$ & $0.00(0.00)$ \\
\hline $\mathrm{D}($ no $R \& D)$ & $-0.18(0.08)$ & $-0.08(0.12)$ & $0.01(0.02)$ & $-0.01(0.01)$ \\
\hline Log age & $0.06(0.03)^{* *}$ & $0.03(0.03)$ & $0.00(0.01)$ & $-0.00(0.00)$ \\
\hline Log employment & $-0.00(0.02)$ & $-0.01(0.05)$ & $0.03(0.01)^{\star * *}$ & $0.01(0.00)^{* *}$ \\
\hline Log employment squared & $-0.00(0.00)$ & $-0.00(0.01)$ & $0.00(0.00)$ & $0.002(0.001)^{* *}$ \\
\hline $\mathrm{D}$ (exports) & $-0.06(0.06)$ & $0.05(0.11)$ & $0.01(0.02)$ & $0.05(0.02)^{\star *}$ \\
\hline $\mathrm{D}$ (member of a group) & $0.06(0.04)$ & $0.02(0.06)$ & $0.06(0.01)^{* * *}$ & $0.02(0.01)^{* * *}$ \\
\hline $\mathrm{D}$ (foreign-owned) & $0.03(0.04)$ & $0.00(0.06)$ & $-0.02(0.01)^{*}$ & $-0.01(0.01)$ \\
\hline R-squared & 0.01 & 0.005 & & \\
\hline Share with dep var $=1$ & & & 0.115 & 0.039 \\
\hline Share correctly predicted & & & 0.906 & 0.962 \\
\hline Share correctly predicted $($ dep var $=1)$ & & & 0.210 & 0.029 \\
\hline Share correctly predicted $($ dep var $=0)$ & & & 0.984 & 0.999 \\
\hline Observations & 4839 & 2668 & 4839 & 2668 \\
\hline
\end{tabular}

Notes: Heteroskedastic-consistent standard errors clustered on enterprise are shown in parentheses.

Period dummies for the three different CIS waves and sector dummies are included in all regressions.

patent application is strongly associated with the new-to-the-market innovation sales share, but in the case of KIBS, it is strongly negative for the new-to-the-firm innovative sales share. We are not sure how to interpret this, although it may be related to variation in the level of vertical integration in these kinds of service firms. That is, research-oriented firms that patent may not have much in the way of innovative sales, since they supply under contract to other firms.

The growth rate regressions for manufacturing are similar to those for all firms, with an insignificant positive association with patenting and more strongly positive association with having trademarks. The coefficients on size and size squared imply that growth falls with firm size until around 300 employees and then increases. In addition, the coefficients of interest in the KIBS regression have very large standard errors, suggesting weak identification. An interesting result is that the relative importance of formal vs informal IP in the three-digit sector is strongly associated with employment growth, even in the presence of the two-digit sector dummies. It is possible that the attitudes toward IP are better predictors in this sector than actual patenting and trademarking because there are relatively few firms that make use of these formal IP mechanisms yet, although there may be more in the future. Another alternative is that patenting and trademarking are somewhat undercounted due to the difficulties of matching the newer and younger firms in these sectors to the IP data. 


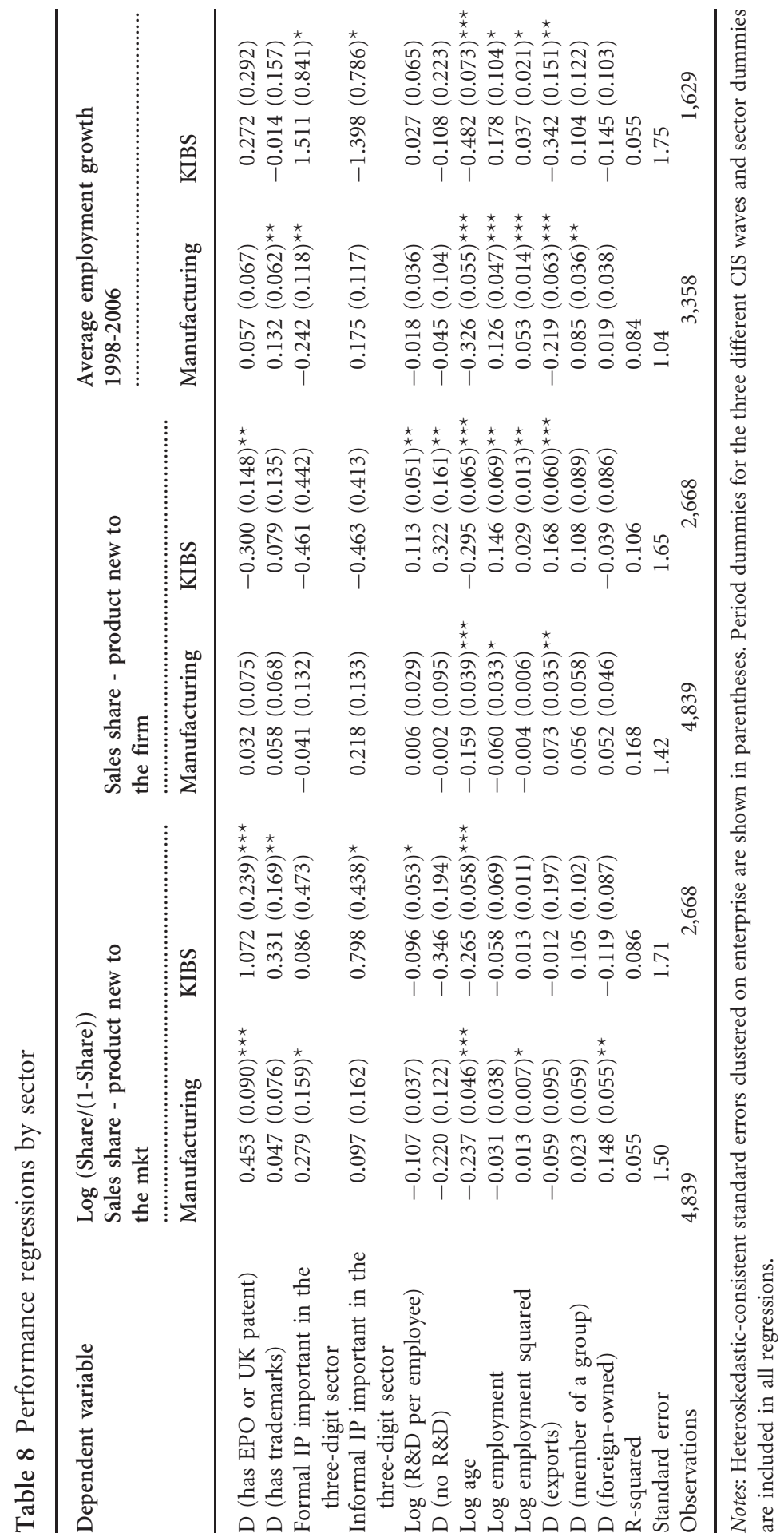




\section{Conclusion}

This paper provides an analysis of the determinants of a firm's patenting decision and assesses the potential implications of the choice on its performance measured as innovative sales and as employment growth. The analysis relies on a new integrated dataset that combines a range of data sources into a panel at the enterprise level. Our findings suggest the following conclusions.

\subsection{Determinants of a firm's choice of IP protection}

Our descriptive analysis shows about one third of UK firms report any form of innovation. Strikingly, we find that only $3 \%$ of firms in our sample patent and that even among firms that conduct $\mathrm{R} \& \mathrm{D}$, only $4 \%$ patent. In particular, the share of patenting firms is much lower than what one might expect given that around $20 \%$ of firms that invest in R\&D report product innovations.

When we investigated the determinants of patenting versus not patenting for innovative firms, we found that most of the predictor variables confirmed prior intuition: patentees are more likely to be product innovators rather than process innovators, more likely to also use trademarks, and they are larger, slightly more likely to export, and to be part of a business group.

What then explains the fact that so few of the firms patent, even if we restrict ourselves to new to the market product innovators that do R\&D? One possible reason is that the samples we are using contain a large number of smaller firms ( $<250$ employees) who may find use of the formal IP system simply too costly. This hypothesis is weakly supported by the small negative coefficients on the presence of financial constraints in both the importance of formal IP vs informal IP and the patent propensity regressions. Certainly size is a very important predictor in our patenting propensity regressions and coupled with the skew size distribution for firms, this can explain the low patenting rate. However, looking at the large sample (which includes sectors that generally do not have patentable inventions), we have seen in earlier work (Hall et al., 2012b) that almost half of the large firms do not use formal or informal IP either. Because firms that use one IP mechanism are more likely to use another, another possibility is that firms have a 'propensity' to use or not use IP, and that the problem is lack of familiarity with the system and suboptimal behaviour on the part of some firms.

A final (and perhaps the most likely) explanation is that the use of any IP protection mechanism costs time and money and most firms find that the benefits do not exceed the costs, especially in the case of patents. ${ }^{20}$ However, our findings on performance call this explanation into question, at least for some firms.

\footnotetext{
${ }^{20}$ The costs of patenting involve not only the direct financial costs of preparing and prosecuting a filing (or paying for specialized counsel), but also indirect costs in form of for example management time. In addition, patents need to be enforced, which requires the monitoring of possible infringement and taking legal action in case infringement is detected. As documented by Helmers and McDonagh (2012), patent litigation in the UK, before the Patents Court, is extremely costly, with costs varying between GBP one and six million for cases heard by the court between 2000 and 2008 .
} 
The large positive association between patenting and innovative sales suggest that there could be non-patenting firms out there that would benefit from using patents or other forms of IP protection.

\subsection{The use of IP protections and (innovative) performance}

The results on innovation performance suggest that patented innovations are more successful in promoting innovative sales. However, because we do not know whether performance and patenting are both driven by the unobservable quality of the firm's innovation or by the quality of the firm itself, it is not possible to make a causal inference based on our analysis that patenting any innovation will lead to better innovative sales performance. In contrast, we do not find any statistically significant association between patenting and employment growth.

\section{Supplementary material}

Supplementary material (the Appendix) can be found on the OUP/OEP website.

\section{Acknowledgements}

We thank the editor Anindya Banerjee and four anonymous referees for helpful comments. The paper was presented at the AEA Meetings 2013, UC Berkeley, and the UK Intellectual Property Office. We thank participants for useful comments. This work contains statistical data from UK ONS which is Crown copyright and reproduced with the permission of the controller of HMSO and Queen's Printer for Scotland. The use of the ONS statistical data in this work does not imply the endorsement of the ONS in relation to the interpretation or analysis of the statistical data. This work uses research datasets which may not exactly reproduce National Statistics aggregates. The views expressed here are those of the authors. They are not necessarily those of the UK Intellectual Property Office.

\section{Funding}

United Kingdom Intellectual Property Office.

\section{References}

Anton, J. and Yao, D. (2004) Little patents and big secrets: managing intellectual property, RAND Journal of Economics, 35, 1-22.

Arundel, A. (2001) The relative effectiveness of patents and secrecy for appropriation, Research Policy, 30, 611-24.

Balasubramanian, N. and Sivadasan, J. (2011) What happens when firms patent? New evidence from US economic census data, Review of Economics and Statistics, 93, 126-46.

Bound, J., Cummins, C., Griliches, Z., Hall, B.H., and Jaffe, A. (1984) Who does R\&D and who patents? in Z. Griliches (ed.) R\&D Patents, and Productivity, University of Chicago Press, Chicago, IL, 21-54.

Brouwer, E. and Kleinknecht, A. (1999) Innovative output, and a firm's propensity to patent. An exploration of CIS micro data, Research Policy, 28, 615-24. 
Giuri, P., Mariani, M., Brusoni, S., Crespi, G., Francoz, D., Gambardella, A., GarciaFontes, W., Geuna, A., Gonzales, R., Harhoff, D., Hoisl, K., Le Bas, C., Luzzi, A., Maggazini, L., Nesta, L., Nomaler, O., Palomeras, N., Patel, P., Romanelli, M., and Verspagen, B. (2007) Inventors and invention processes in Europe: results from the PatVal-EU survey, Research Policy, 36, 1107-27.

Hall, B.H. (1987) The relationship between firms size and growth in the US manufacturing sector, Journal of Industrial Economics, 35, 583-606.

Hall, B.H., Helmers, C., Rogers, M., and Sena, V. (2012a) The choice between formal and informal intellectual property: a review, NBER Working Paper No. 17983, Cambridge, MA.

Hall, B.H., Helmers, C., Rogers, M., and Sena, V. (2012b) The use of alternatives to patents and limits to incentives, UK Intellectual Property Office Report 2012/21, Newport.

Heger, D. and Zaby, A. (2013) The heterogeneous costs of disclosure and the propensity to patent, Oxford Economic Papers, 65, this issue.

Helmers, C. and McDonagh, L. (2012) Patent litigation in the UK, LSE Law, Society and Economy Working Papers 13/2012, London.

Hussinger, K. (2006) Is silence golden? Patents versus secrecy at the firm level, Economics of Innovation and New Technology, 15, 735-52.

Mairesse, J. and Mohnen, P. (2010) Using innovation surveys for econometric analysis, in B.H. Hall and N. Rosenberg (eds) Handbook of the Economics of Innovation, Elsevier, Amsterdam and New York, ch. 4.

Mansfield, E. (1986) Patents and innovation: an empirical study, Management Science, 32, 173-81.

Pajak, S. (2010) Do firms rely on big secrets? An analysis of IP protection strategies with the CIS 4 survey, available at SSRN: http://ssrn.com/abstract=1538980 (accessed 26 February 2013).

Rogers, M., Helmers, C., and Greenhalgh, C. (2007a) An Analysis of the Characteristics of Small and Medium Enterprises that Use Intellectual Property, UK Intellectual Property Office, Newport, available at http://www.ipo.gov.uk/ipresearch-characteristics-200710.pdf (accessed 26 February 2013).

Rogers, M., Helmers, C., and Greenhalgh, C. (2007b) An Analysis of the Characteristics of Small and Medium Enterprises that Use Intellectual Property, UK Intellectual Property Office, Newport, available at http://www.ipo.gov.uk/ipresearch-association-200710.pdf (accessed 26 February 2013).

Sakakibara, M. and Branstetter, L. (2001) Do stronger patents induce more innovation? Evidence from the 1988 Japanese patent law reforms, Rand Journal of Economics, 32, 77-100.

Scherer, F.M. (1965) Corporate inventive output, profits and growth, Journal of Political Economy, 73, 290-7.

Scherer, F.M. and Weisburst, S. (1995) Economic effects of strengthening pharmaceutical patent protection in Italy, International Review of Industrial Property and Copyright Law, 26, 1009-24.

Wilson, R.A. and Homenidou, K. (2012) Working futures, UK Commission for Employment and Skills, Evidence Report No. 41, London, available at http://www.ukces. org.uk (accessed 26 February 2013). 